BANCA D'ITALIA

E U R O S I S T E M A

Questioni di Economia e Finanza

(Occasional Papers)

The growth of the service sector and demand for services

by Eliana Viviano 

13 BANCA D'ITALIA

E U ROS I S T E M A

\section{Questioni di Economia e Finanza}

(Occasional papers)

The growth of the service sector and demand for services

by Eliana Viviano

Number 290 - September 2015 
The series Occasional Papers presents studies and documents on issues pertaining to the institutional tasks of the Bank of Italy and the Eurosystem. The Occasional Papers appear alongside the Working Papers series which are specifically aimed at providing original contributions to economic research.

The Occasional Papers include studies conducted within the Bank of Italy, sometimes in cooperation with the Eurosystem or other institutions. The views expressed in the studies are those of the authors and do not involve the responsibility of the institutions to which they belong.

The series is available online at www.bancaditalia.it .

ISSN $1972-6627$ (print)

ISSN 1972-6643 (online)

Printed by the Printing and Publishing Division of the Bank of Italy 


\title{
THE GROWTH OF THE SERVICE SECTOR AND DEMAND FOR SERVICES
}

\author{
by Eliana Viviano*
}

\begin{abstract}
In this paper I present evidence about the relevance of the composition of the demand for services in the development of the sector. By comparing the evolution of the demand for services in Italy, France, Germany and the US, I first show that the contribution of final demand by households to the development of market services is lower in Europe than in the US. In Europe the share of output produced by market services and used by the manufacturing sector is almost twice as high as the average value recorded in the US. The manufacturing sector, however, tend to consume low-skill services like distributive trade services and inland transportation. Compared with the European countries, the higher growth rate of market services in the US (and of high-skill market services) is then probably due to higher demand by US households.
\end{abstract}

JEL Classifications: O47, C67, E01.

Keywords: service sector, demand for services, input-output, tertiarization.

\section{Contents}

1. Introduction

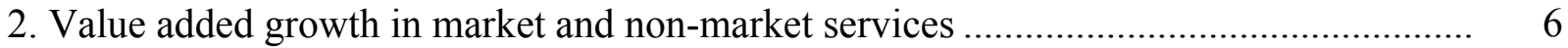

2.1. Quantities

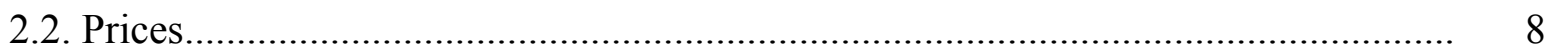

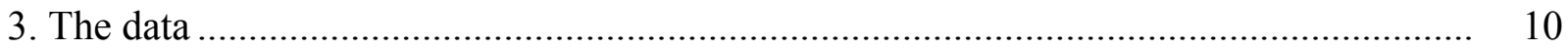

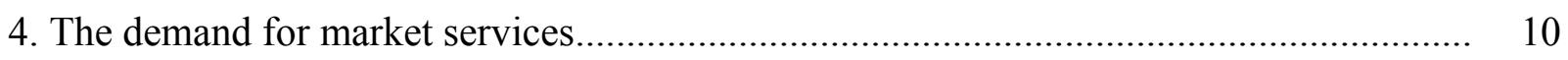

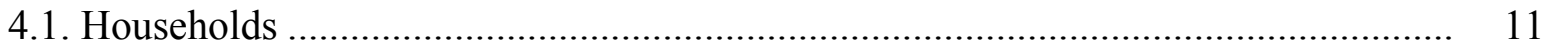

4.2. Intermediate consumption …............................................................ 14

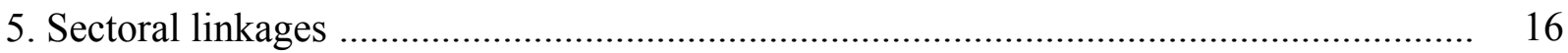

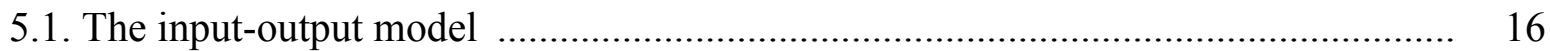

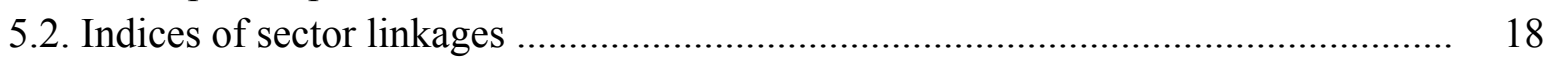

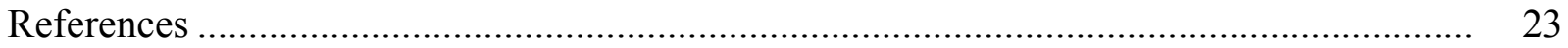

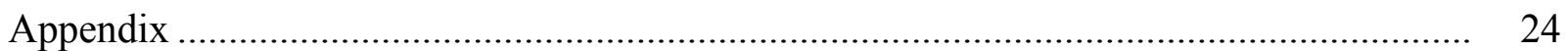

\footnotetext{
* Bank of Italy, Directorate General for Economics, Statistics and Research.
} 



\section{Introduction}

One of the most striking trends of the post-1950 US economy has been the rising importance of the service sector, mainly driven by the development of skill-intensive services. This has stimulated a debate about the slower growth rate of services in Europe, especially in those countries, like Italy, plagued by unsatisfactory economic performance.

Explanations tend to focus on supply-side factors, like limits to competition, labour market rigidities, insufficient reallocation of resources. In this note I focus instead on the demand for services. The importance of a demand-driven approach has been stressed, among others, by Buera and Kaboski (2012), who argue that the long-term growth of the US skill-intensive services (e.g. finance, professional activities, etc.) has been determined by the increasing demand by household for market services relative to home production.

I first describe the general trends observed in Germany, France, Italy and the US, by looking at "quantities" and prices. The data confirm the considerable growth of the service sector from 1991 to 2012. Then I focus on market services and in particular on the development of the demand by households and firms, which use services as intermediate inputs in their production function. Finally, I analyze sector linkages, focusing mainly on linkages between services and manufacturing.

The analysis suggests that from 1991 to 2012 in the three European countries here considered the process of "terziarization" has evolved at similar rates. At the end of the period the ratio between market services value added and manufacturing value added was equal to 4.4 in the US, 4 in France, 3 in Italy, 2 in Germany.

The contribution of final demand by households to the development of market services is lower in Europe than in the US. In Italy, from 1995 to 200936 per cent of the market services gross output growth at constant prices has been due to the rise of household final consumption (68 per cent in the US, 56 per cent in Germany and France).

Compared to Europe, the demand for market services by US households has been probably fostered by a relatively more favorable dynamics of prices for final consumption.

In all the European countries here analyzed the development of market services is closely related with the growth and the weight of manufacturing. The share of market services used as intermediate inputs by manufacturing is very similar in Italy and Germany. On average, during the period 1995-2011 around 16 per cent of output produced in market services was used by the manufacturing sector, almost twice as high as the average value recorded in the US during the same period.

Considering also indirect linkages it turns out that the output multiplier of manufacturing in all the four countries is higher than the output multiplier of market services. Moreover, in all countries $1 / 4$ of the manufacturing output multiplier is due to the use of market services by manufacturing. 
Sector linkages do not differ greatly across countries. In Italy, Germany and France the manufacturing sector demands for low skill intensive services, like wholesale and retail trade and transportation. OLS estimates show that there is a positive correlation between the weight of manufacturing in total output and the share of low skill services in total market services.

Sector linkages between manufacturing, distributive trade and transports are relatively stronger in Italy compared to Germany and France, probably because of the structure of the Italian manufacturing sector, fragmented in many small and geographically widespread firms.

Overall, the analysis outlines that the most striking difference between the three European countries and the US is the different weight of household final demand in total market services output. This difference also explains large part of the gap in output growth. Many factors concur to explain this gap. Among other things, the results presented in this note suggest that further research is needed to investigate differences not only in income dynamics but also in price dynamics. All these topics are also closely related to the study of the determinants of the higher weight of manufacturing in Europe, which ultimately depends on degree of vertical integration within manufacturing and on the organization of production within and across countries.

\section{Value added growth in market and non-market services}

\subsection{Quantities}

During the past two decades in many advanced economies the importance of the service sector increased considerably. As shown by Figure 1, from 1991 to 2012 currentprice value added of services increased by more than 120 per cent in France, by 100 per cent in Germany and by around 80 per cent in Italy (panel a). In the US, where the growth of service sector started in the sixties and accelerated in the eighties (see e.g. Buera and Kaboski, 2012), from 1991 to 2012 value added at current prices continued to increase considerably ( 280 per cent at the end of the period). The gap between Europe and US is even larger if we consider quantities. Value added at constant prices increased by more than 80 per cent in the US, 50 per cent in Germany and France and by around 30 per cent in Italy, contributing in all the European countries to more than $2 / 3$ to the growth of GDP. In the US the growth of GDP is almost totally due to the service sector.

The service sector is a composite aggregate which can be broken down in many ways. Here I consider market services (including wholesale and retail trade, transportation, hotels and restaurants, information and communication, finance, real estate activities and professional and administrative services) and the so-called "non-market services sector", including services mainly supplied, in Europe, by the public sector (public administration, health and education, arts, recreation and other services to households). Market services are produced for sale on the market, while non-market services are services provided to the community or individuals at a fee which is in general below production costs. Figure 2, which reports the growth of real value 
added in these two main sub-sectors, suggests that the higher contribution to the growth of services comes from market services, whose weight in total services was around 75 per cent in Italy in 2012, around 70 per cent in France and Germany and higher than 80 per cent in the US. Thus, the worse performance of total services in Italy compared to Germany and France (and in European countries compared with the US) is largely due to market services.

Figure 1

Value added growth in the service sector at current (panel a) and constant prices (panel b) (1). Index: $1991=100$

(a)

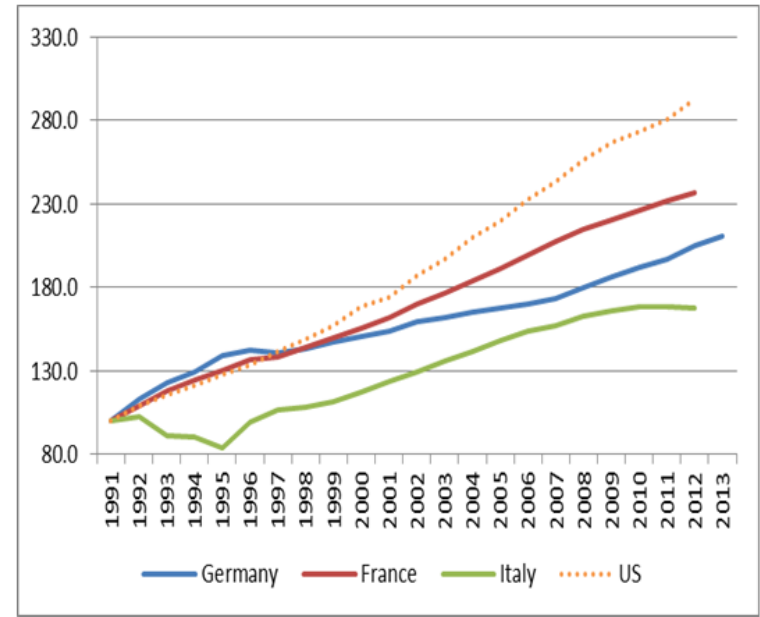

(b)

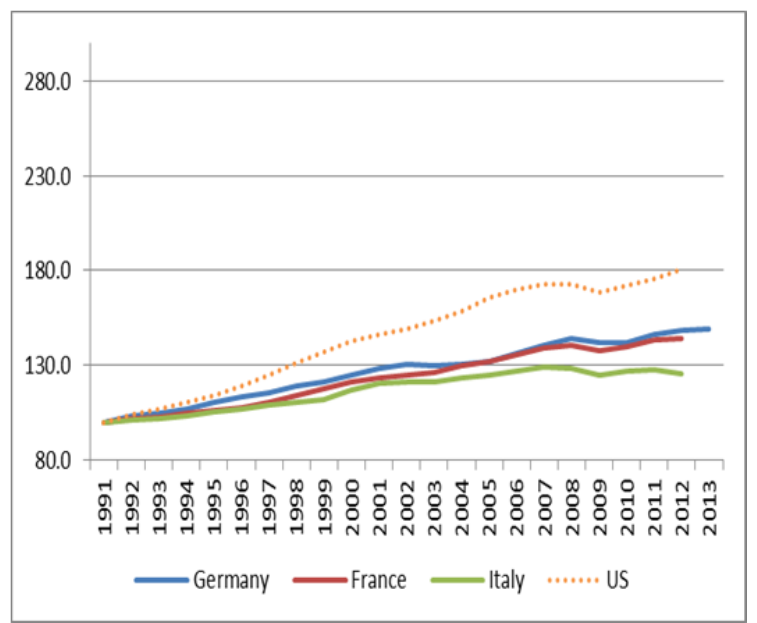

Source: elaboration on Eurostat and Bureau of Economic Analysis data. (1) Chain-linked volumes, reference year 2000 (at 2000 exchange rates), for the European countries; Chain-linked volumes reference year 2009 for the US.

The growth of the service sector can be analyzed also in relative terms, i.e. by comparing it with the growth of the manufacturing sector. Figure 3 reports the ratio between valued added in market services and value added in manufacturing (at current prices in panel a and constant prices in panel b, 1991=100). In all the three European countries this index of "tertiarization" increased considerably, especially during the late nineties. While the index at current prices shows a sharp increase in France, the same ratio at constant prices suggests, instead, that tertiarization was more intense in Germany immediately after, and probably because of, the structural change induced by the reunification. In the US, instead, since the process of tertiarization begun immediately after the fifties and accelerated at the end of the seventies (see Buera and Kaboski, 2012), from 1991 to 2012 market services and manufacturing increased at similar rates. The US economy remains, however, the one in which the ratio between value added in services and in manufacturing remains higher (4.4 in 2012, against 4.0 in France, 3 in Italy and 2 in Germany). 
(a)

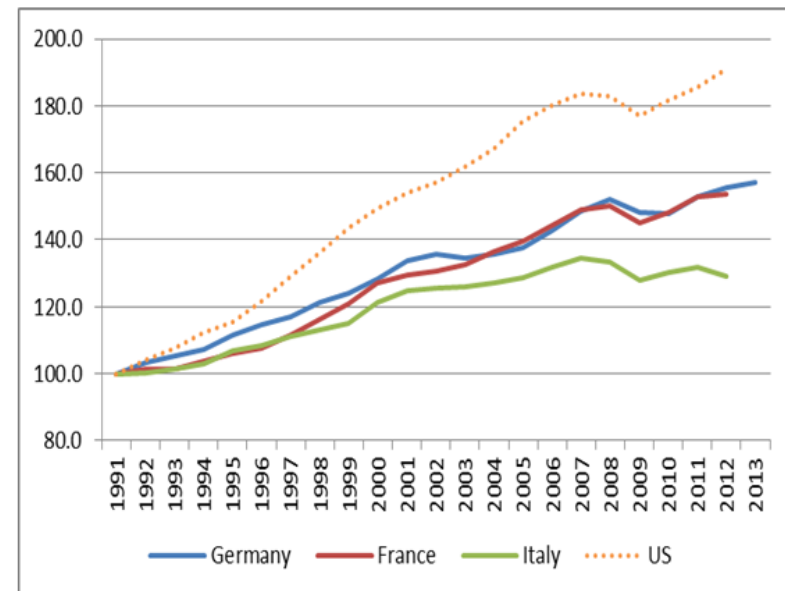

(b)

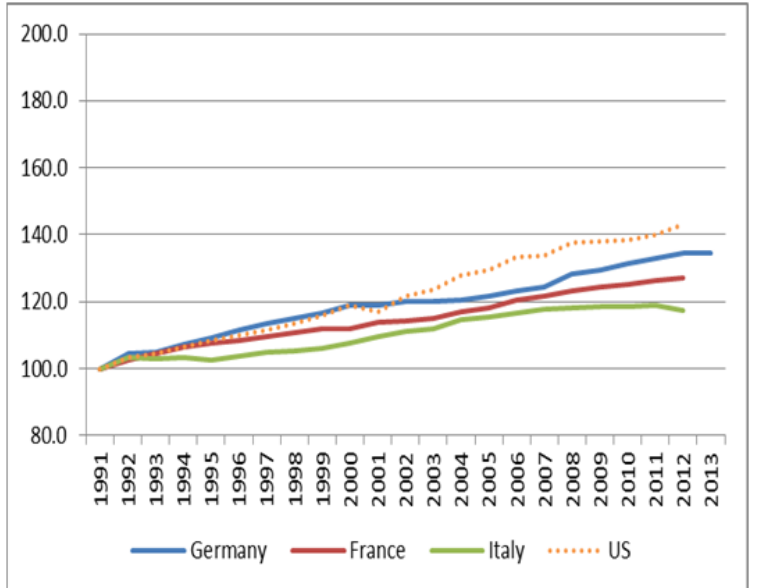

Source: elaboration on Eurostat and Bureau of Economic Analysis data. (1) Chain-linked volumes, reference year 2000 (at 2000 exchange rates), for European countries, reference year 2009 for the US.

\subsection{Prices}

The sizeable cross-country differences in the dynamics of current and constant price value added, and in the services to manufacturing value added ratio suggest that prices diverged not only across countries, but also across the two sectors. Figure 4 reports a proxy $^{1}$ for the value added deflator in market services (panel a) and the ratio between the deflators for market services and manufacturing. This index can be viewed as a proxy for relative prices of services and manufacturing and has been used by Barca and Visco (1993) to explore inflation differentials among the same group of European countries from 1977 to 1990. Barca and Visco (1993) find that, compared with Germany and France, during the eighties in Italy the relative price of market services increased considerably. This trend, explained by the very low level of competition in market services, was one of the main factors driving the unfavorable total inflation observed in Italy during that period.

Figure 4 shows that the price of services increased by more than 80 per cent in Italy, by 40 per cent in France and US and by 20 per cent in Germany. However, in relative terms (panel b) the growth rate was higher in France (58 per cent), smaller in Italy (28 per cent) and roughly constant in Germany and the US.

\footnotetext{
${ }^{1}$ The proxy is calculated by averaging sub-sector price indexes by the share of subsector current-price value added. This proxy tend to bias price changes associated to large variation in quantities. For more precise price comparisons, Figure A1 in the Appendix reports value added deflators by subsectors. Figure A2 reports the corresponding ratio between the price of service and the price of manufacturing goods.
} 
Figure 3

Ratio between value added in market services and in manufacturing at current prices (panel a) and constant prices (panel b (1)). Market services only. Index: 1991=100

(a)

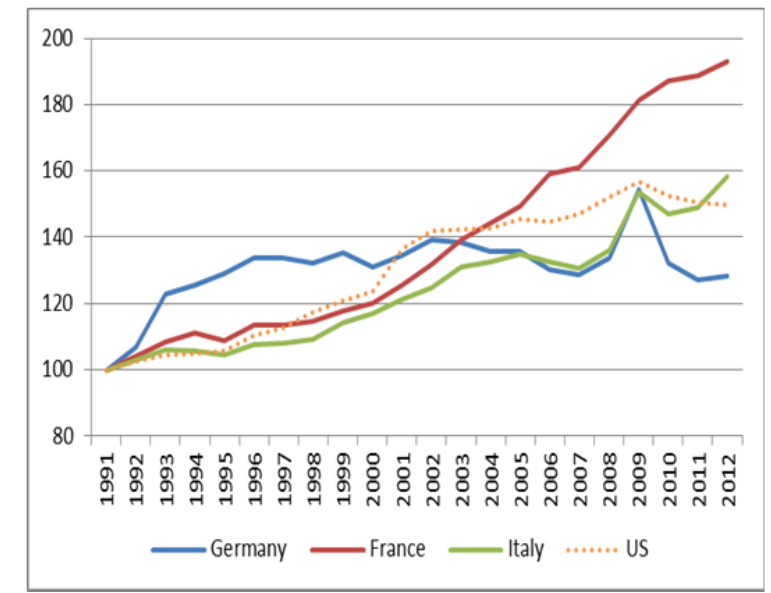

(b)

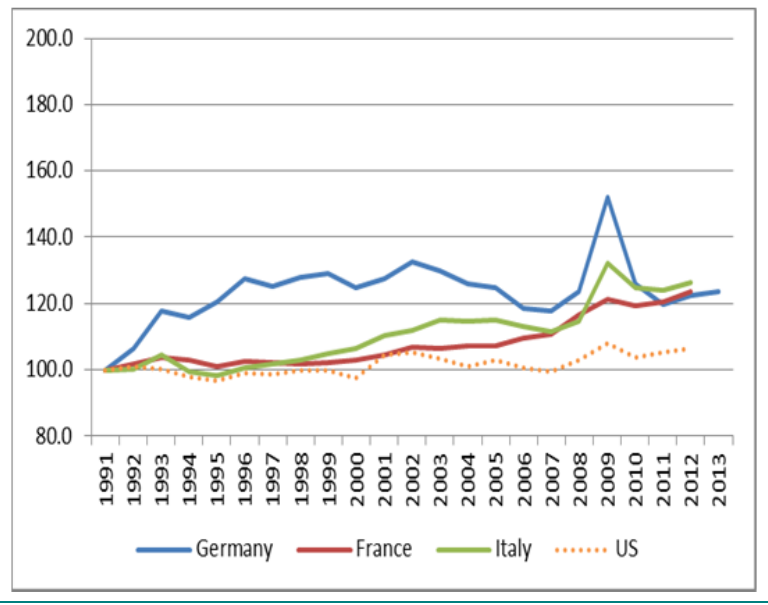

Source: elaboration on Eurostat and Bureau of Economic Analysis data. (1) Chain-linked volumes, reference year 2000 (at 2000 exchange rates). for European countries, reference year 2009 for the US.

From the one hand, the joint analysis of Figures 3 and 4 confirm that in all the countries here considered both prices and quantities of market services increased considerably. From the other hand, they confirm that service inflation -both in absolute and in relative terms- is in Italy remarkably higher than in Germany. As shown by Barone and Cingano (2011), however, higher services' regulation, because of its negative impact on prices, negatively affects also the economic performance of manufacturing. Whether and to what extent the unfavorable competiveness of Italian manufacturing depends on structural characteristics of the Italian economy -common to both manufacturing and services- or on the pass-through from services to manufacturing remains an open issue, extremely relevant for competitiveness, which is left for future research.

However, in this note, it is worth mentioning that, while Barca and Visco (1993), pointed out the role of retail trade and transports in driving the dynamics of prices during the eighties, more recent data by services subsector suggest that compared with Germany, the more pronounced growth of prices in Italy depends on real estate activities (which also include renting and operating of own or leased real estate and buying and selling of own real estate) and, to a less extent, on professional services (see fig. A1 and A2 in the Appendix, reporting the same ratios of Figure 4 by services sub-sectors). This change is likely to be due to the effects of the intense process of liberalization of retail trade started in 1998, which increased productivity and reduced prices (see Schivardi and Viviano, 2011, Viviano et al., 2013, and Ciapanna and Genito, 2014). ${ }^{2}$

\footnotetext{
${ }^{2}$ Even if the first panel of Figure A2 refers to the larger subsector "Wholesale and retail trade, transport, accommodation and food service activities", for which we have a longer time series, the ratio calculated only on wholesale and retail trade, available from 1999 to 2009 confirms what reported in Figure A2.
} 
Figure 4

Market services. Value added deflator (panel a) (1) and ratio between deflators in market services and manufacturing (panel b). Index: 1991=100

(a)

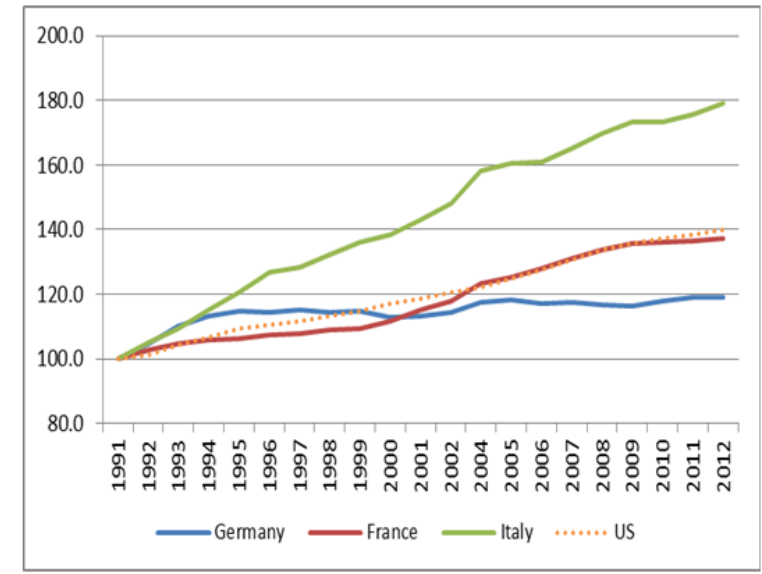

(b)

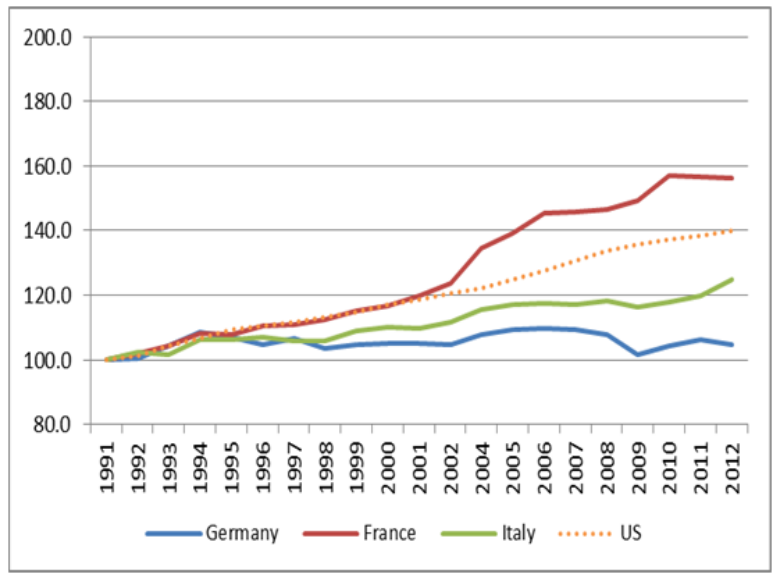

Source: elaboration on Eurostat and Bureau of Economic Analysis data.

\section{The data}

The possibility to calculate comparable statistics for all the countries here considered and to investigate the linkages between market services and the other sectors in a country is provided by the World input-output database (WIOD) recently made available for the period 1995-2011 at current prices. Values are expressed in US dollars, but the dataset includes also an average exchange rate. The WIOD database, together with the World input output tables used to account for global value chains, provides also national tables for 38 countries, including Italy, Germany, France and the US.

More in detail, two types of datasets are released within the WIOD project: currentprices input output tables ${ }^{3}$, available from 1995 to 2011, and aggregate statistics on output, value added and corresponding deflators for the shorter period 1995-2009. ${ }^{4}$

The quality of WIOD data is in general good. To evaluate at least indirectly the reliability of WIOD datasets the input output matrices for Italy have been compared with the ones provided by Istat for the years 1995, 2000 and 2005, and they give similar information on changes sector linkages. Istat tables however are not fully comparable with WIOD because of differences in the definition of branches.

\section{The demand for market services}

In this section I analyze the growth of market services by a demand perspective, i.e. by considering the use of market services by households, firms and the government. Let $x_{i}$ represents gross output in sector $i$, let $z_{i j}$ be the amount of output of sector $i$ used as

3 World input-output tables, November 2013 release, (http://www.wiod.org/new_site/database/wiots.htm). 4 Social-economic accounts, February 2013 release, (http://www.wiod.org/new_site/database/seas.htm). 
intermediate input by sector $j$, let $C_{i}$ represent private consumption of good/service $i ; F_{i}$ is gross capital formation; $G_{i}$ government consumption; $E_{i}$ exports. Then: ${ }^{5}$

$$
x_{i}=\sum_{j} z_{i j}+C_{i}+F_{i}+G_{i}+E_{i}
$$

The term $\sum_{j} z_{i j}$ is equal to the total intermediate consumption of the good/service produced by $i$-th industry. The right hand side of equation [1] corresponds to the total demand for domestic products.

Let $i$ in equation (1) denote market services. I ignore for the moment the terms $E_{i}$ and $F_{i}$ and I focus on the ratio between households, government, other sectors' consumption and total output $x_{i}$. I then calculate the contribution of each demand component to the growth of market services.

\subsection{Households}

To appreciate the importance of household consumption in the development of market services, Figure 5 reports the share of market services consumed by households in total gross output of market services (panel a) and in total household consumption of manufacturing products and services (panel b).

Figure 5

Share of market services consumed by households in total market services gross output (panel a) and household final demand (panel b) (1). Current prices.

(a)

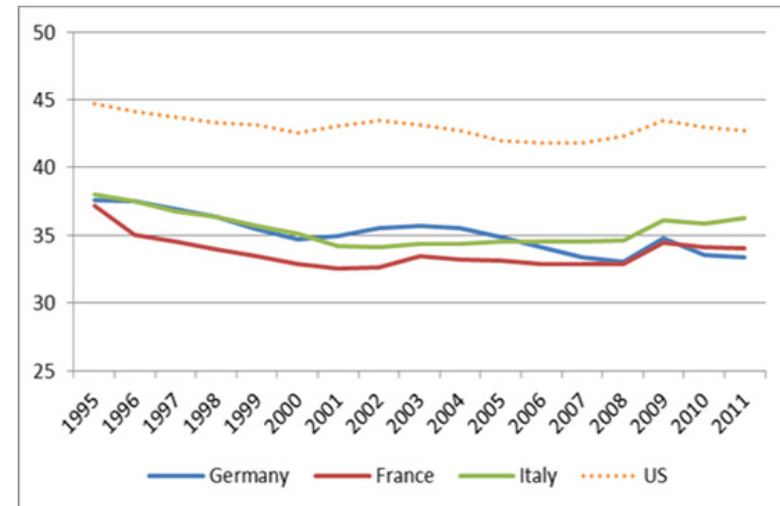

(b)

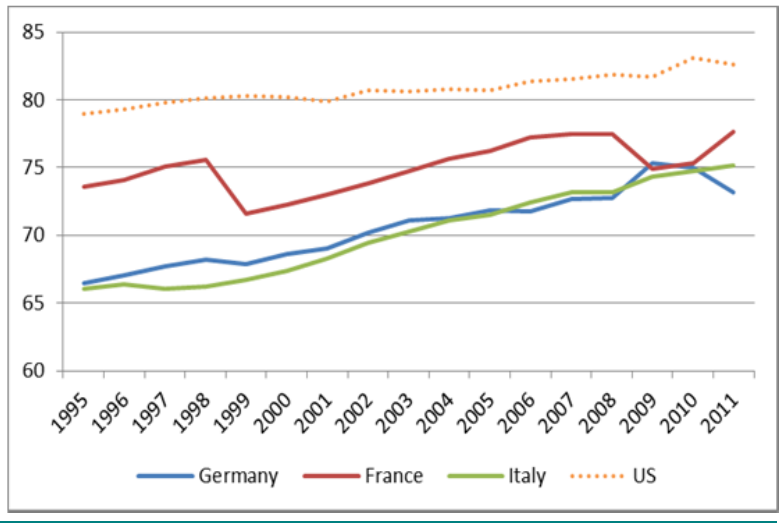

Source: elaboration on WIOD. Current prices. (1) In panel $\mathrm{b}$ the share is calculated as the ratio between household consumption of market services and total household consumption of manufacturing products and market services.

Panel a shows that the share of market services output consumed by households was between 33 and 36 per cent in all the 3 European countries and almost 10 percentage points higher in the US. A closer look to market services subsectors reveals that the

\footnotetext{
${ }^{5}$ Aggregating by sector, we get the relationship $\mathrm{X}=\mathrm{II}+\mathrm{C}+\mathrm{F}+\mathrm{G}+\mathrm{E}$, where $\mathrm{X}$ is output and II are intermediate inputs. The same relationship from the supply side is equal $X=I I+M+V A$, where $\mathrm{M}$ are imports and VA is value added.
} 
difference between the 3 European countries and the US are mainly due to distributive trade, typically classified as a low skill sector (see Table 1).

These results are very similar to the finding of Rémond-Tiedrez (2013), based on the European consolidated input-output tables for 2008 and 2009 and the US input-output tables produced by the Bureau of Economic Analysis. ${ }^{6}$

Table 1

Share of household consumption in total gross output, by service subsector, 2011.

\begin{tabular}{lllll}
\hline & Germany & France & Italy & US \\
Wholesale and retail trade & 39.4 & 41.7 & 33.6 & 61.3 \\
Hotel and restaurants & 89.5 & 75.2 & 76.8 & 76.9 \\
Transport & 29.1 & 36.4 & 29.4 & 34.0 \\
Post and telecommunications & 44.9 & 39.0 & 37.1 & 39.0 \\
Financial intermediation & 36.8 & 32.3 & 32.8 & 31.9 \\
Real estate activities & 63.8 & 65.9 & 65.0 & 70.1 \\
Professional activities & 3.5 & 3.2 & 5.4 & 9.8 \\
Total market services & 33.4 & 34.1 & 36.3 & 42.7 \\
\hline
\end{tabular}

Source: elaboration on WIOD input output data. Current prices.

Panel b of Figure 5 shows that the share of market services consumed by households in total household consumption of services and manufacturing products. Again differences between the US and the European countries are remarkable, being the share of services consumed by households around 70 per cent in Italy and Germany, 75 per cent in France and higher than 80 per cent in the US. This gap is mainly due to higher share of consumption spent in distributive trade services, professional activities and financial intermediation services by US households (see Table 2). The joint analysis of Tables 1 and 2 suggests then that differences in the relative weight of household demand for services not only depend on differences in the economic structure, but also on household demand composition.

The lower weight of household consumption in total consumption of services may depend on many factors, like differences in disposable income, in price dynamics, in the relatively higher weight of manufacturing in the European countries here considered (under the assumption of supply constraints) and in household preferences (more oriented in Europe to home production). From an empirical point of view it is extremely difficult to identify the causes behind the lower development of market services in the European countries. However it is likely that price dynamics plays a role in shaping the demand by households.

\footnotetext{
${ }^{6}$ Rémond-Tiedrez (2013) finds that household in the US consume around 59 per cent of total output produced in the transportation, accommodation and food services. This share is 46 per cent in the European Union. The gap is equal to 10 percentage points in the information and communication sector. This sector, however, cannot be identified when using WIOD data which are based on NACE Rev. 1.
} 
Table 2

Household consumption by sub-sector in total consumption of manufacturing products and market services, 2011.

\begin{tabular}{lllll}
\hline & Germany & France & Italy & US \\
Wholesale and retail trade & 18.2 & 20.8 & 19.9 & 26.2 \\
Hotel and restaurants & 7.5 & 8.6 & 13.8 & 10.0 \\
Transport & 4.7 & 5.3 & 5.9 & 2.9 \\
Post and telecommunications & 4.3 & 3.5 & 3.0 & 3.7 \\
Financial intermediation & 10.5 & 8.0 & 6.7 & 11.9 \\
Real estate activities & 25.9 & 28.0 & 22.0 & 23.1 \\
Professional activities & 2.0 & 2.1 & 2.1 & 4.5 \\
Total market services & 73.1 & 77.6 & 75.2 & 82.6 \\
\hline
\end{tabular}

Source: elaboration on WIOD input output data. Current prices.

As shown in section 2.2 in all the countries here considered, and especially in Italy, during the period 1991-2012 the deflator of market services increased. The deflator of market services, however, is the weighted sum of the deflators of final and intermediate consumption.

Figure 6

Market services: Ratio between the deflator for household final consumption and for total gross output. 1995-2009

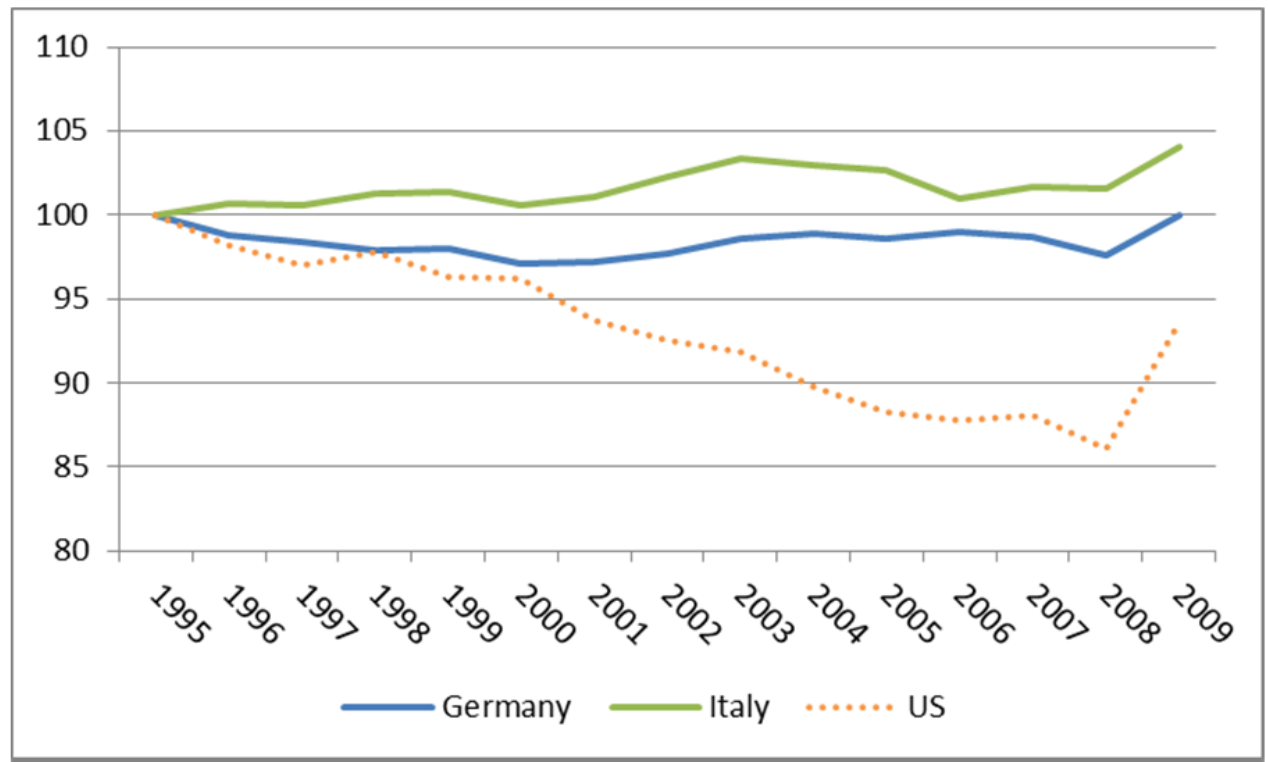


Figure 6 reports the ratio, based on the WIOD database, between the deflator of household final consumption and of total output in market services from 1991 to 2009 (data on France are unfortunately not available). Figure 6 suggests that in the US the 40 per cent increase in the output deflator depicted in Figure 4 has been driven by a more rapid increase in prices for intermediate consumption, while prices charged to households followed a more flat pattern. In Germany price deflators of intermediate and final consumption increased roughly at the same rate. In Italy prices charged to households increased slightly faster than prices charged to firms. Therefore, it is possible to conclude that compared to Europe (at least part) of the high demand for market services in the US has been fostered by a relatively more favorable dynamics of prices for final consumption.

Even if not fully comparable, because of different subsector classification Figure A3 in the Appendix mimics Figures A1 and A2 and reports the ratio between household consumption deflator and total output deflator by subsector. The Figure shows that the more favorable price pattern for households in the US has been driven by distributive trade and transports, while in Italy and Germany this ratio remained constant. Differently from Italy, in Germany the ratio increased in the financial sector, while it declined significantly in post and communication and real estate activities.

Finally, Figure A4 in the Appendix reports the share of government consumption of market services. The corresponding series is not available for the US, but, given the characteristics of the US welfare state it is unlikely that the growth of market services in this country has been driven by government consumption. Figure A4 shows that in the European countries the share of market services consumed by the government is very low and constant over time, with the exception of France. In all, these figures suggest that differently from the US, the development of market services in Europe is more closely related to the development of the demand by other sectors, while household demand has a lower weight.

\subsection{Intermediate consumption}

The first panel of Figure 7 reports two components of the term $\sum_{j} z_{i j}$ : the share of market services output used as intermediate input by manufacturing (panel a) and the share of market services used as intermediate inputs by market services (panel b).

First, the share of market services used as intermediate inputs by manufacturing firms is very similar in Italy and Germany. On average, during the period 1995-2011 around 16 per cent of output produced in market services was used by the manufacturing sector, almost twice as high as the average value recorded in the US during the same period. Second, in all the countries the share of market services used as intermediate inputs by the market services increased: in 2011 it was around 30 per cent in Italy and France, slightly lower in Germany and in the US. Summing up, in the European countries the intermediate consumption of market services by manufacturing and by market services covers around 45 per cent of the total output of market services. This share is remarkably lower in the US, mainly because of the very low share of services sold to the US manufacturing sector. The 
same picture holds if we consider constant prices data. These results are also consistent with the finding of Rémond-Tiedrez (2013) for the European Union.

Figure 7

Share of market services used as intermediate inputs by manufacturing (panel a) and by market services (panel b) in total gross output of market services. Current prices.

(a)

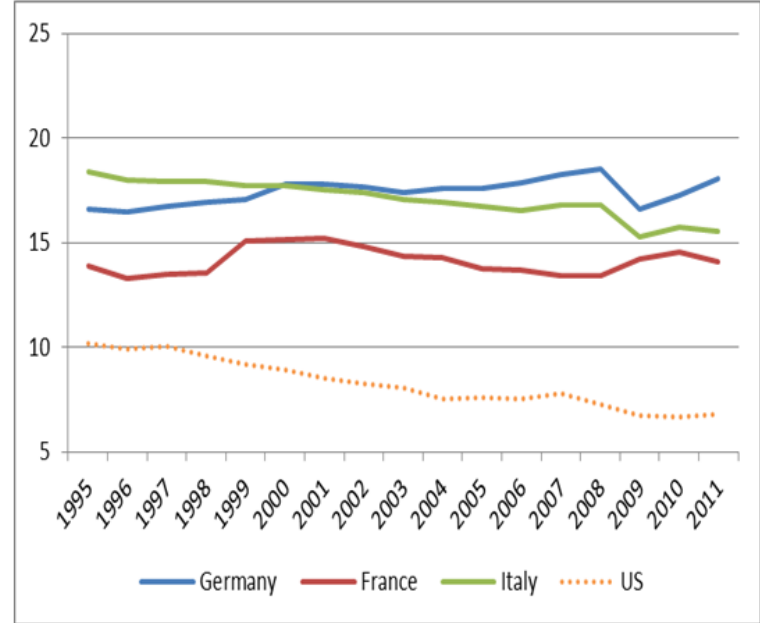

Source: elaboration on WIOD. Current prices. (b)

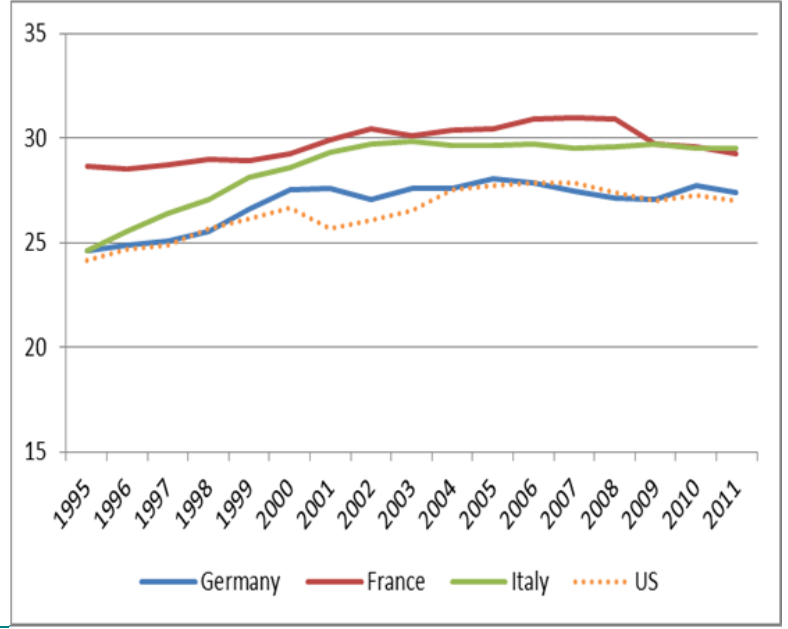

To give a more comprehensive picture, Figure 8 reports the growth of total gross output at constant prices during the period 1995-2009 and the contribution to growth of household final consumption and the demand for intermediate inputs. First, as expected gross output at constant prices grew faster in the US than in Europe. Growth was mainly driven by household consumption. Second, also in Germany and France household consumption of market services explains more than one half of the growth of total gross output. In Italy, where the growth rate of gross output was slower, the contribution of intermediate inputs was predominant, while the contribution of household final consumption to total gross output growth was equal to just $1 / 3$. 


\section{Sectoral linkages}

\subsection{The input-output model}

Given the relevance of the demand for intermediate inputs in the development of market services in Europe in this section I focus on direct and indirect linkages between market services and manufacturing, and within market services. ${ }^{7}$ To account for indirect effects, in this section I focus on the index of sectoral linkages proposed by Rasmussen (1956) and Jones (1986), calculated on WIOD national input-output tables at current prices. ${ }^{8}$

Figure 8

Gross output growth rate at constant prices and contribution of household final demand and intermediate input consumption

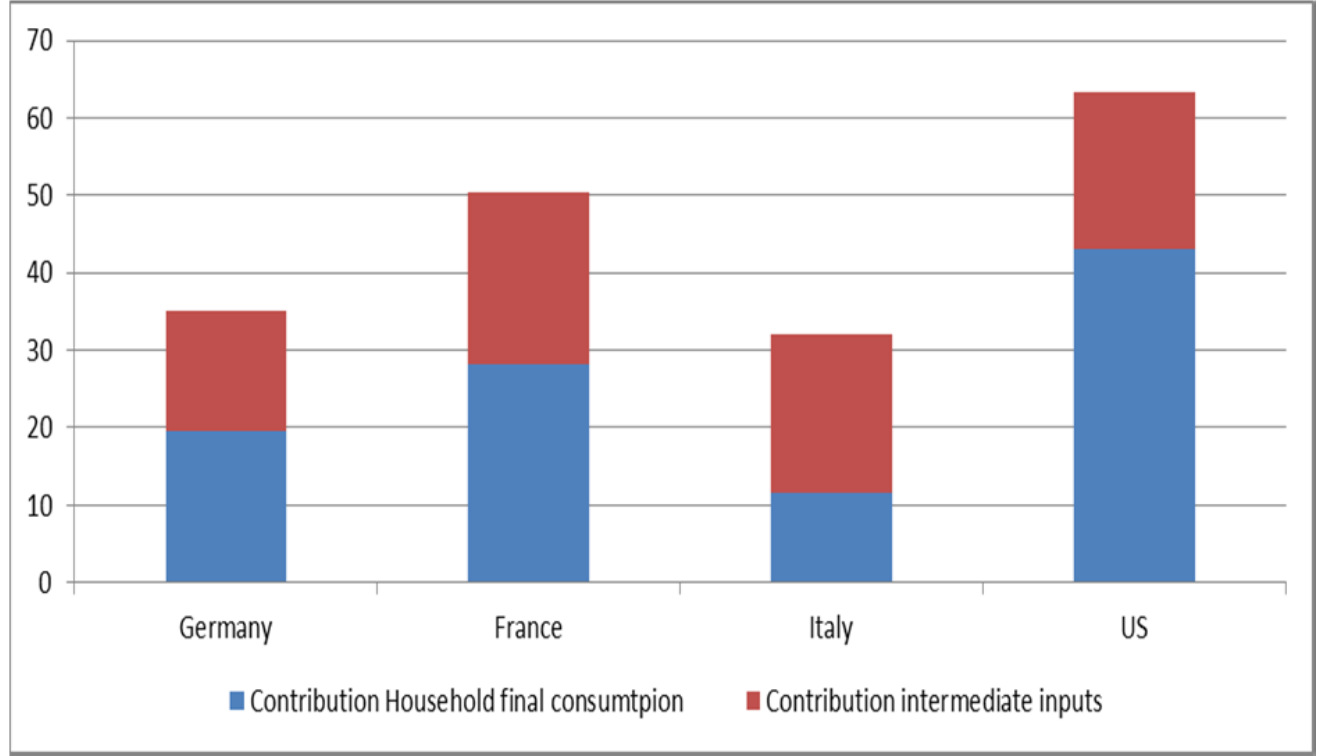

Source: elaboration on WIOD input output data. Current prices.

Using the same notation of the previous section, let $a_{i j}=z_{i j} / x_{j}$ be equal to the share of product $i$ used as input in the production of one monetary unit of industry $j$ 's output. Assuming that there are $n$ sectors in the economy, Equation [1] can then be written as

$$
x_{i}=a_{i 1} x_{i 1}+\cdots+a_{i n} x_{i n}+f_{i}
$$

where $f_{i}$ stands for total final demand of product $i$ (i.e. $f_{i}=C_{i}+F_{i}+G_{i}+E_{i}$ ), or in matrix terms,

\footnotetext{
${ }^{7}$ For instance, an increase in the demand by manufacturing for services may generate (1) an increase in market services sold to manufacturing as intermediate consumption plus (2) an increase in sales of other services, if also the services directly bought by manufacturing need other services as intermediate inputs.

${ }^{8}$ WIOD data are expressed in US dollars, by the WIOD database includes also the exchange rate and allows one to estimate values at national currency.
} 


$$
\boldsymbol{x}=\boldsymbol{A x}+\boldsymbol{f}
$$

which is equal to:

$$
x=(I-A)^{-1} f=L f
$$

The matrix $(\boldsymbol{I}-\boldsymbol{A})^{-1}$ is the so called Leontief inverse. Assuming a small exogenous change in the final use vector $(\Delta \mathbf{f})$, the corresponding change in the output vector $(\Delta \mathbf{x})$ is equal to $(\boldsymbol{I}-\boldsymbol{A})^{-1} \Delta \mathbf{f}=\mathbf{L} \Delta \mathbf{f}$, under the assumption that the technical coefficients are constant with respect to exogenous changes in final demand (this assumption being more plausible for small changes in final demand).

The inverse can be rewritten as:

$$
(I-A)^{-1}=I+A+A^{2}+A^{3}+. .+A^{k}+. .
$$

Therefore

$$
\Delta x=\Delta f+A \Delta f+A^{2} \Delta f+A^{3} \Delta f \ldots
$$

Thus, when the vector of final demand increases by $\Delta \mathrm{f}$, this causes an initial effect of the same amount on $\Delta \mathrm{x}$, equal to the first term. To satisfy this additional output, sectors have to buy additional inputs, given by $\mathbf{A} \Delta \mathbf{f}$. However the production of those new inputs also requires intermediate consumption of additional inputs. These are the so-called indirect effects, represented by the terms $A^{2} \Delta \mathbf{f}+\mathbf{A}^{3} \Delta \mathbf{f} \ldots$.

The element $\mathrm{l}_{\mathrm{ij}}$ of the Leontief inverse $\mathbf{L}=(\boldsymbol{I}-\boldsymbol{A})^{-1}$ is then equal to the value of output $i$ required directly and indirectly to deliver one additional monetary unit to j's final demand. The backward index proposed by Rasmussen (1956) is:

$$
L_{j}=\sum_{i} l_{i j}
$$

and measures the impact on the whole economy caused by a change in the final demand for output $j$. This index is labeled as "backward", as it measures the impact of an increase in the final demand of good $j$ on suppliers of intermediate inputs. $L_{j}$ is also often referred as the output multiplier of sector $j$.

In this note I use the backward index, even if raw, as a tool to study how an increase in final demand for manufacturing goods directly and indirectly affects the output of market services in Italy, France, Germany and the US. For this purpose I consider the following sub-indexes. Let $i, j=M, S$ denote the manufacturing sector and the market-services sector respectively. Assume that the input output table is disaggregated in $n_{M}$ subsectors of manufacturing and $n_{S}$ subsectors classified in market services.

Then: 


$$
L_{j}=\sum_{i \in S} l_{i j}+\sum_{i \in M} l_{i j+} \sum_{i \notin M S} l_{i j}
$$

where the first term measures the impact of an increase in sector $j$ 's final demand on $S$, the second term represents the total effect on manufacturing and the third is the impact on other sectors like construction, energy, agriculture and non-market services.

\subsection{Indices of sectoral linkages}

In this section, using WIOD data, backward indexes are calculated at current prices and excluding imports, ${ }^{9}$ i.e. they measure the effect on domestic production/sales only (the final demand vector includes instead gross exports). ${ }^{10}$ The backward index at current prices coincides with the one based on constant-price input-output tables if all good/services are sold at a single price, i.e. the price of commodities/services does not differ across buyers (under this assumption prices can be viewed as a constant vector in equation [2]). If instead prices differ across buyers, the backward index at current prices is biased and the bias depends on how much each cell-specific deflator is far from aggregate sectoral total intermediate consumption deflator. Unfortunately, constant-price input-output tables are not available. I then mainly focus on changes in current-prices backward indexes over time, and rely on the single-price assumption. The index then represents the value of output required directly and indirectly to deliver one additional monetary unit to j's demand

In this section, I calculate two different backward indexes, one for manufacturing and one for market services and then I decompose them based on [5] $]^{11}$. Backward indexes in 2011 and the corresponding sub-components are reported for each country in Table 3. The top panel of the Table refers to the effects of a unit increase in total final demand for manufacturing goods. In all the countries the effect on manufacturing is around 30 per cent (1 unit due to the increase in final demand and .3 points due to the term $\boldsymbol{A}+\boldsymbol{A}^{\mathbf{2}}+$ $\left.\boldsymbol{A}^{\mathbf{3}}+. .+\boldsymbol{A}^{\boldsymbol{k}}+..\right)$. The impact of manufacturing on sales of market services is instead larger in Italy and France than in Germany and the US. The effect on other sectors is instead low in the European countries and larger in the US. The total effect of an increase in final demand for manufacturing goods is around .9 in all the countries, with the exception of Germany where it is equal to 0.65. The differences between Germany and the US, from the one side, and France and Italy, from the other, are likely to depend on the higher vertical integration of manufacturing firms in the first group of countries, where the average size of manufacturing firms in 2011 was around 35 employees (9 and 15 in Italy and France respectively).

\footnotetext{
${ }^{9}$ Dietzenbacher and Temurshoev (2012) show however that constant price indexes do not differ greatly from current prices indexes, unless large differences of deflators of sales from sector $i$ to sector $j$ from the gross output deflators of sector $\mathrm{j}$.

10 Since I exclude imports, the term $\mathrm{a}_{\mathrm{ij}}$ is not the technical coefficient of the production function, but it is must be interpreted as a domestic sales coefficient.

11 WIOD input output tables refer to 35 subsectors. The backward index of manufacturing, $\mathrm{L}_{\mathrm{M}}$ is calculated by aggregating all the subsectors of manufacturing. Similarly the backward index of market services $L_{S}$ is calculated by aggregating all the subsectors composing market services.
} 
The bottom part of the table represents the impact of a unit increase in final demand for market services on various subsectors. In all the countries the effect on market services is comprised between 40 per cent in the US and 47 per cent in Italy. The impact of an increase in final demand for market services on manufacturing and on other services is negligible.

Table 3

\section{Backward indexes for a unit increase in final demand for manufacturing products and for market services, by sub-components.}

\begin{tabular}{lllll}
\hline & Germany & France & Italy & US \\
& & & & \\
Unit increase in manufacturing & & & \\
& & & & \\
Effect on: & & & & \\
Manufacturing & 1.26 & 1.30 & 1.33 & 1.34 \\
Market services & 0.35 & 0.52 & 0.48 & 0.33 \\
Other sectors & 0.05 & 0.08 & 0.06 & 0.15 \\
Total output multiplier & 1.65 & 1.90 & 1.93 & 1.86 \\
& & & & \\
& & & & \\
Unit increase in market services & & & \\
& & & & \\
Effect on: & 0.05 & 0.07 & 0.12 & 0.08 \\
Manufacturing & 1.41 & 1.45 & 1.47 & 1.40 \\
Market services & 0.07 & 0.05 & 0.08 & 0.06 \\
Other sectors & 1.53 & 1.57 & 1.60 & 1.51 \\
Total output multiplier & Source: elaboration on WIOD input output data. Current prices. & \\
\hline \multicolumn{4}{l}{}
\end{tabular}

More importantly, in spite of the fact that the weight of manufacturing in total economy declined dramatically since the beginning of the nineties (being equal to less than 20 per cent in France, to 20 per cent in Italy and to 25 per cent in Germany, see also Ciapanna and Genito 2014), in Italy and France the impact of manufacturing on market services is larger than the effect of market services on market services themselves, after removing the unit increase in final demand for market services. For example, in Italy, a unit increase in manufacturing is associated with a .52 per cent increase in market services, larger than 0.47 (equal to 1.47 minus a 1 increase in final demand for market services, see equation 3). Figure 9 reports the same subcomponents of the backward indexes from 1995 to 2011. Panel a refers to the effect of a unit increase in the final demand for manufacturing products on market services. Panel $b$ reports the effect of an increase in the final demand for market services on market services, after removing the unit increase in its final demand from 1995 to 2011. Panel a shows that both in Italy and France the effect on services of an increase in manufacturing final demand has a positive trend, especially 
between the end of the nineties and the beginning of 2000s, while the impact remained constant in Germany and declined in the US. Many factors can explain the trends observed in France and Italy, for instance a more intensive outsourcing of services from manufacturing in these countries than in Germany and the US, and/or the growth of imported market services from abroad. Panel b shows instead that until the mid-2000 also sector linkages within market services increased in all the countries (panel b) and then remained constant, but at a smaller level than in manufacturing.

For a comparison Figure A6 in the Appendix reports the indexes measuring the indirect effect of an increase in final demand for manufacturing on manufacturing and the effect of an increase in the final demand for market services on manufacturing. These figures, together with the ones presented in Table 3 confirm that the total output multiplier of manufacturing has been always higher than the output multiplier of market services for all the countries here considered.

Figure 9

\section{Backward indexes. Effect of an increase of final demand for manufacturing products on market services (panel a) and effect of an increase of final demand for market services on market services (panel b)}

(a)

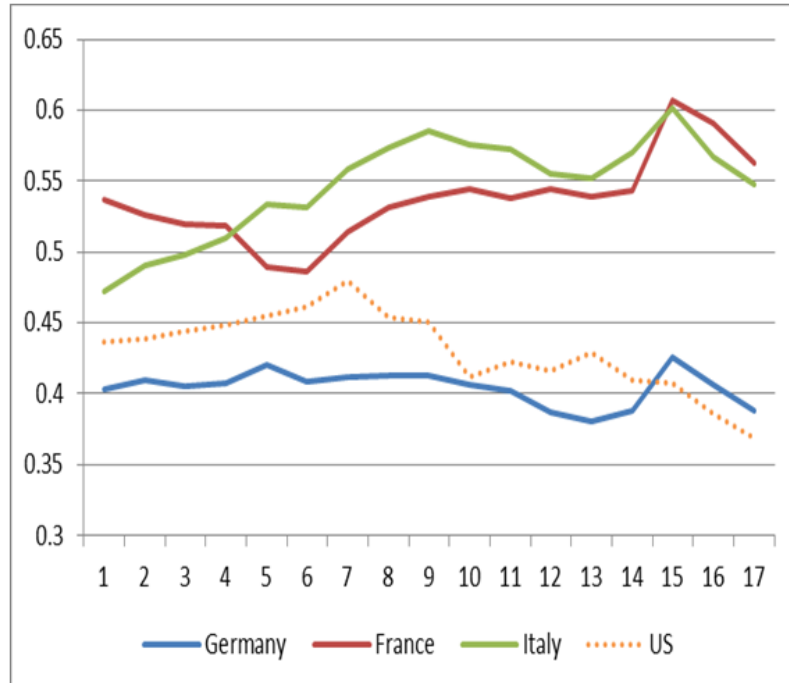

(b)

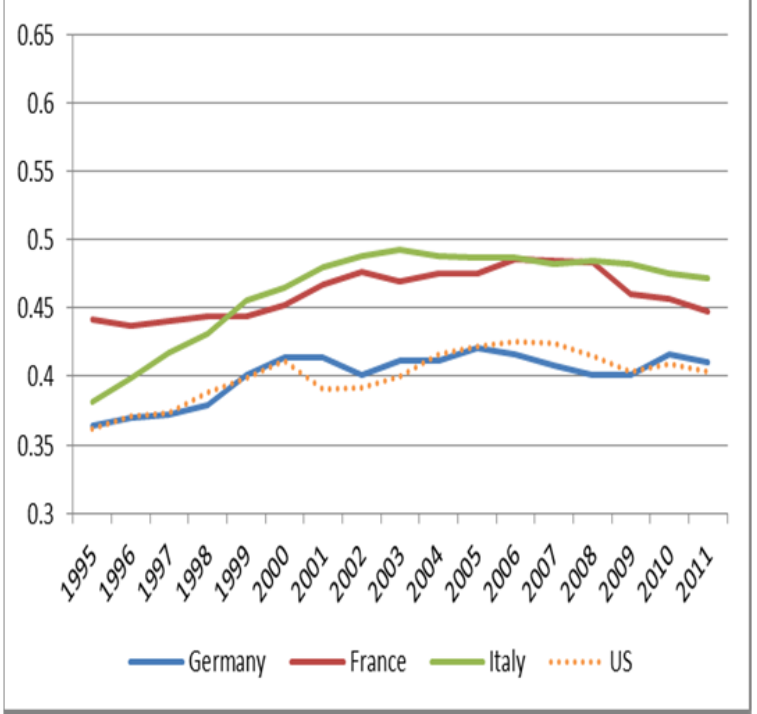

Source: elaboration on WIOD input output data. Current prices.

For a better understanding of the importance of the demand by manufacturing, Table 4 reports the components of the backward index of manufacturing for each of the subsectors constituting the market services aggregate. The comparison with France, Germany and US allows also to shed some light on the composition of demand coming from manufacturing to market services in the different countries and the existence of structural differences, if any. First of all, the Table shows that the European countries have very similar intersectoral linkages and that they do not differ greatly from the US. The only relevant difference concerns wholesale and retail trade and inland transports. 
Compared with Germany, a unit increase in the Italian manufacturing final demand has a higher effect on wholesale and retail trade and inland transports than in Germany, probably because of the structure of the Italian manufacturing industry, highly fragmented not only by size of firms, but also geographically. If we instead compare business services in Italy and Germany (renting, professional activities, other business services), i.e. the so called high skill intensity sectors, in both countries a unit increase in the final demand for manufacturing is associated to a .12-.13 points increase in business services, like in the US. The value for France is instead remarkably higher (.22) and explains most of the differences among France and the other countries. This large effect may be due, however, to the very large increase in prices of these services observed in France during the period 1995-2011 (see Figure A1 and A2).

Table 4

\section{Components of the backward index for a unit increase in final demand for manufacturing. Effect on market services by sub-sectors.}

\begin{tabular}{lcccc}
\hline & Germany & \multicolumn{2}{l}{ France } & \multicolumn{2}{l}{ Italy } \\
& 0.01 & 0.01 & 0.02 & 0.00 \\
Sale, maint. motor vehicles & 0.05 & 0.09 & 0.10 & 0.07 \\
Wholesale trade & 0.04 & 0.05 & 0.06 & 0.01 \\
Retail trade & 0.00 & 0.01 & 0.02 & 0.01 \\
Hotels and restaurants & 0.02 & 0.02 & 0.06 & 0.03 \\
Inland transport & 0.00 & 0.00 & 0.00 & 0.00 \\
Water transport & 0.00 & 0.00 & 0.00 & 0.00 \\
Air transport & 0.02 & 0.03 & 0.02 & 0.01 \\
Other Supporting transport & 0.01 & 0.01 & 0.01 & 0.02 \\
Post, telecomm. & 0.03 & 0.05 & 0.04 & 0.06 \\
Financial intermediation & 0.03 & 0.02 & 0.03 & 0.01 \\
Real estate activities & 0.13 & 0.22 & 0.12 & 0.13 \\
Rent., Profess., Other business & 0.35 & 0.52 & 0.48 & 0.34 \\
Total & & & & \\
\hline
\end{tabular}

Source: elaboration on WIOD input output data. Current prices. Subcomponent of the backward index of manufacturing.

Ultimately, the cross-country comparison presented in Table 4 suggests that the demand for services by manufacturing is similar in all the countries here considered and 
that the development of market services in all countries is closely related with the growth and the weight of manufacturing. This result can be generalized to a wider set of countries. In figure $10 \mathrm{I}$ plot, for all the 38 countries of the WIOD dataset and all the available years, the share of manufacturing value added in total valued added and the share of value added in low skill services in total value added of market services. The figure shows a positive and significant relationship, which remain highly significant when also country fixed effects and time trends are included (and standard errors are adjusted for heteroskedasticity). When the relative weight of manufacturing increases also the weight of low skill services in total services increases, indirectly confirming that the composition of market services is strongly related to the composition of the demand for services.

Figure 10

Correlation between the share of manufacturing value added in total value added and the share of low skill market services in total market services.

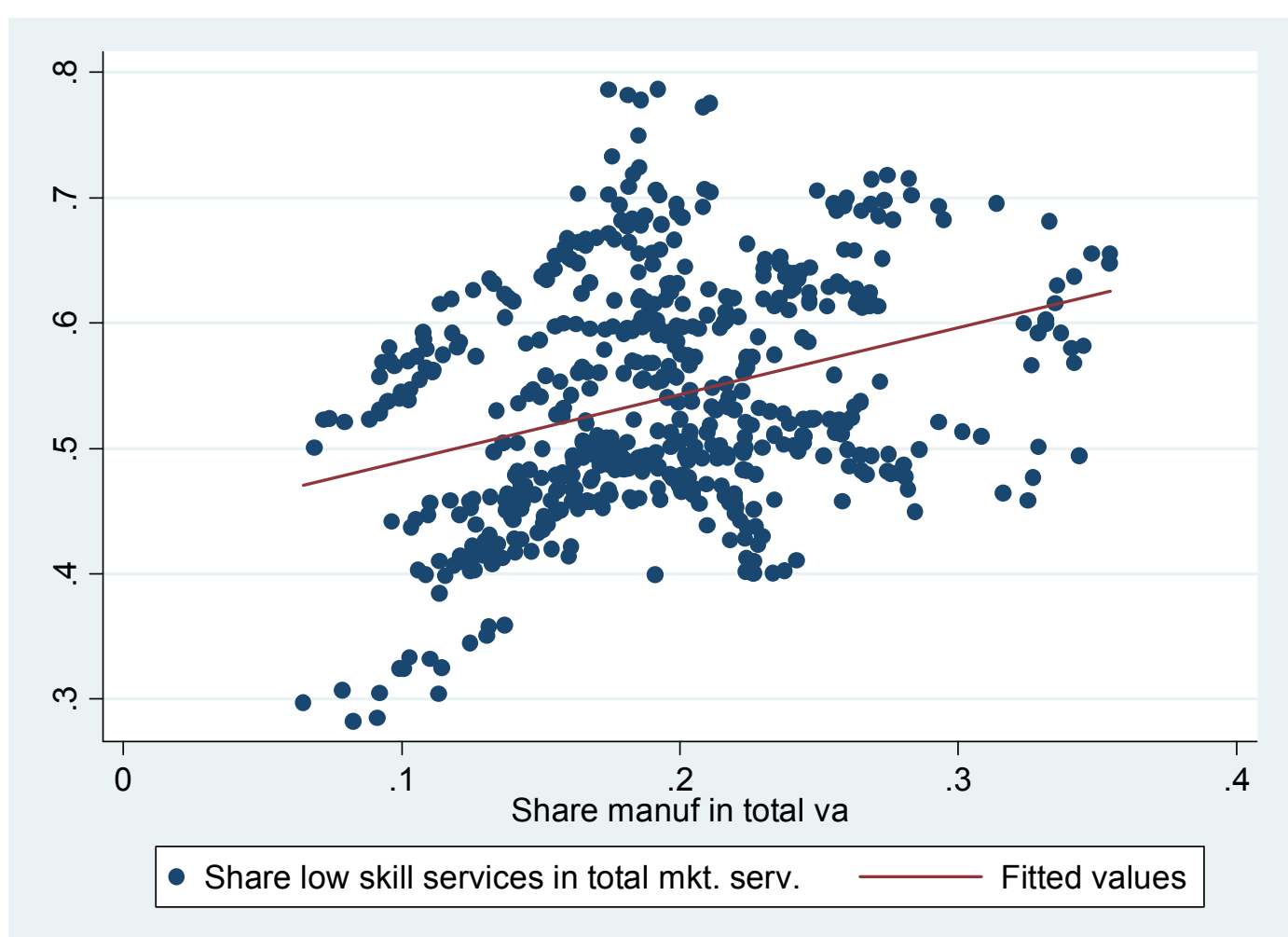




\section{References}

Barca F. and I. Visco, "L'economia italiana nella prospettiva europea: terziario protetto e dinamica dei redditi nominali", in Inflazione, concorrenza e sviluppo, edited by di S. Micossi e I. Visco, il Mulino, Bologna 1993.

Barone G. and F. Cingano (2011) "Service regulation and growth: Evidence from OECD countries", The Economic Journal, 121, 931-957.

Buera F. J. and J. P. Kaboski (2012) "The Rise of the Service Economy", American Economic Review, 102(6): 2540-2569

Ciapanna E. and E. Genito (2014) "The service sector in the euro area: Structure and dynamics in Germany, France and Italy", Bank of Italy, (mimeo).

Dietzenbacher E. and U. Temurshoev (2012) "Input-output impact analysis in current or constant prices: does it matter?" Journal of Economic Structures, 1:4.

Yuskavage, R. E. H. Strassner, and G. W. Medeiros, (2006) "Outsourcing and Imported Services in BEA's Industry Accounts" wp. Bureau of Economic Analysis.

Jones L. P. (1976) "The Measurement of Hirschmanian Linkages", Quarterly Journal of Economics, Vol. 90, No. 2, pp. 323-333.

Schivardi F. and E. Viviano (2011) "Entry barriers in retail trade" The Economic Journal, 121, 145-170.

Rasmussen M. P. (1956), Studies in Intersectoral Relations, Amsterdam, North Holland.

Rémond-Tiedrez (2013) "Consolidated supply, use and input-output tables", Statistics in focus, KS-SF-13-024-EN-N, Eurostat.

Viviano E., L. Aimone Gigio, E. Ciapanna, D. Coin, F. Colonna, F. Lagna e R. Santioni (2012) "La grande distribuzione organizzata e l'industria alimentare in Italia", Bank of Italy, Questioni di economia e finanza, n. 119. 


\section{Appendix}

Figure A1

Value added deflator for market services sub-sectors. Index: 1991=100

Wholesale and retail trade, transport, accommodation and food service activities

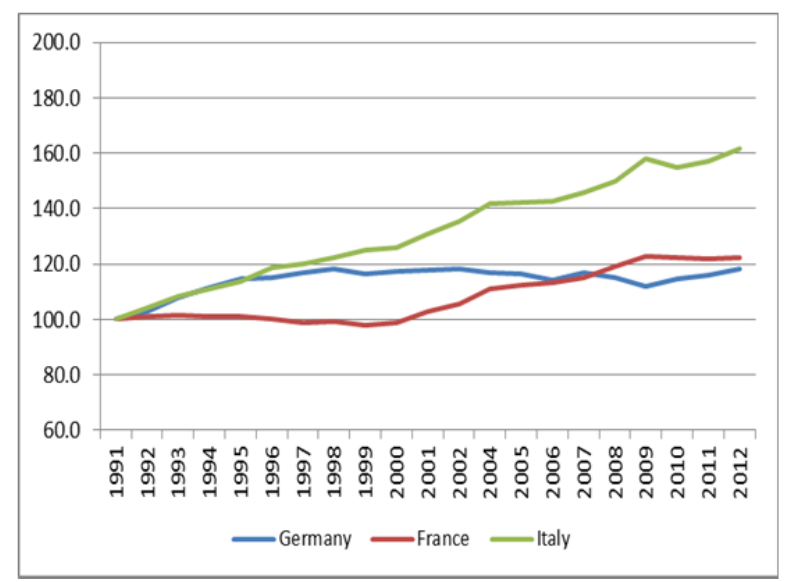

Financial and insurance activities

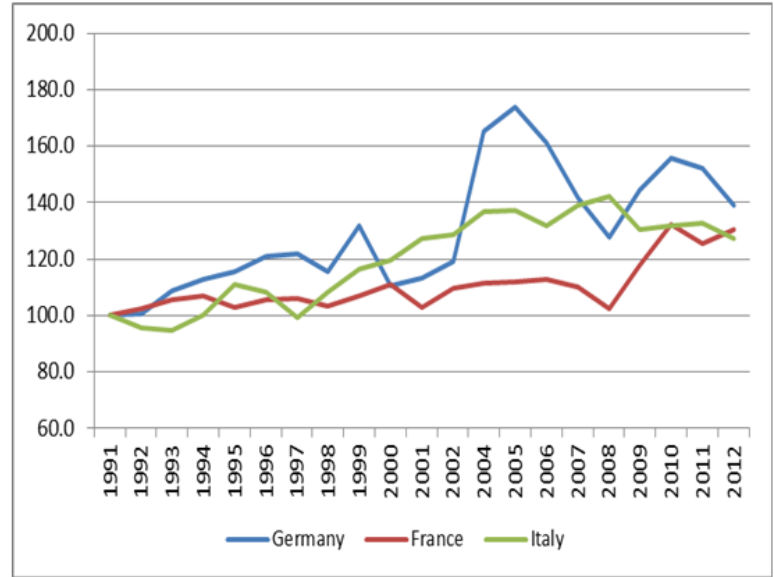

Professional, admin. and support activities

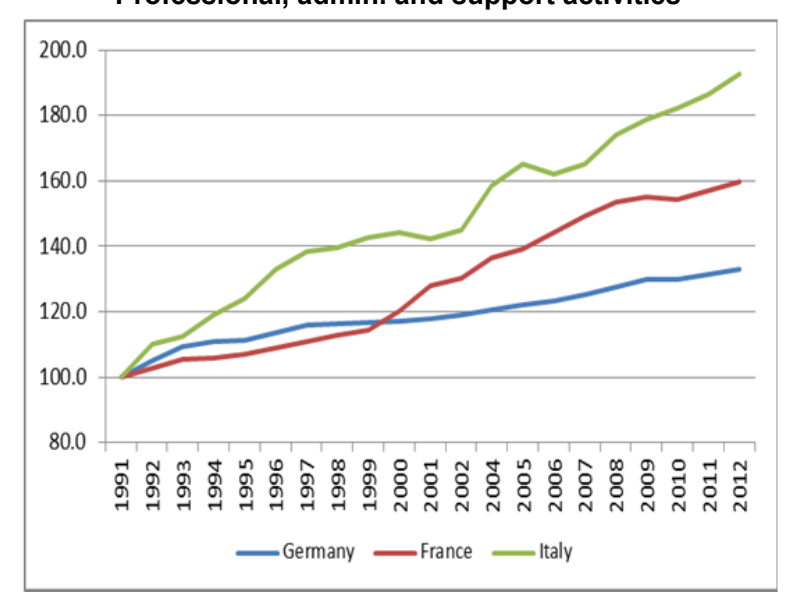

Information and communication

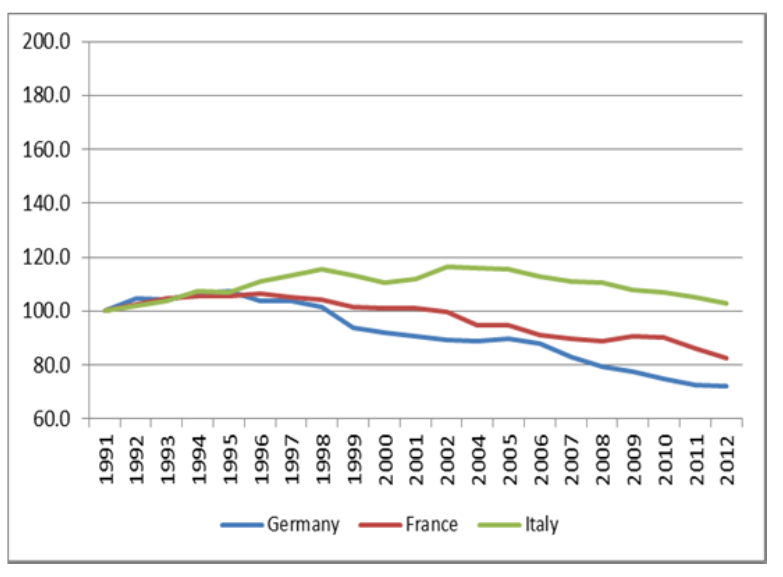

Real estate activities

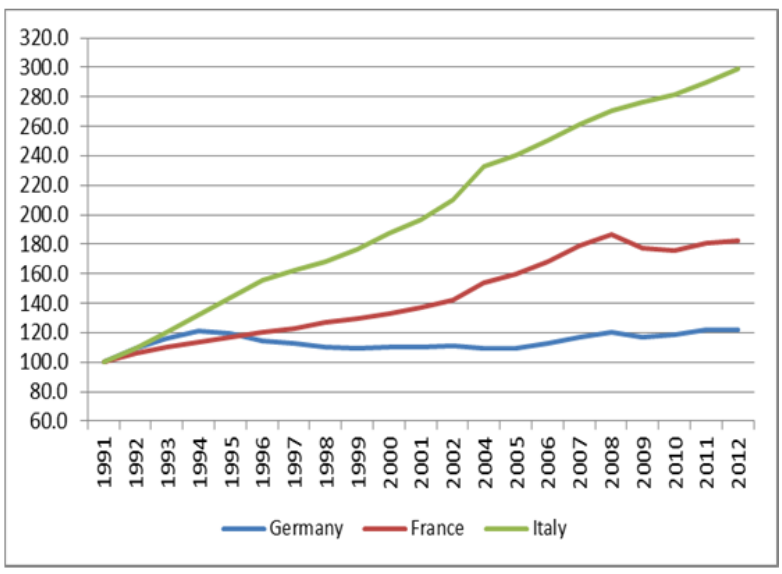

Source: elaboration Eurostat data. 
Figure A2

Ratio between deflators in market services and manufacturing. Index: 1991=100

Wholesale and retail trade, transport, accomodation and food service activities

Information and communication

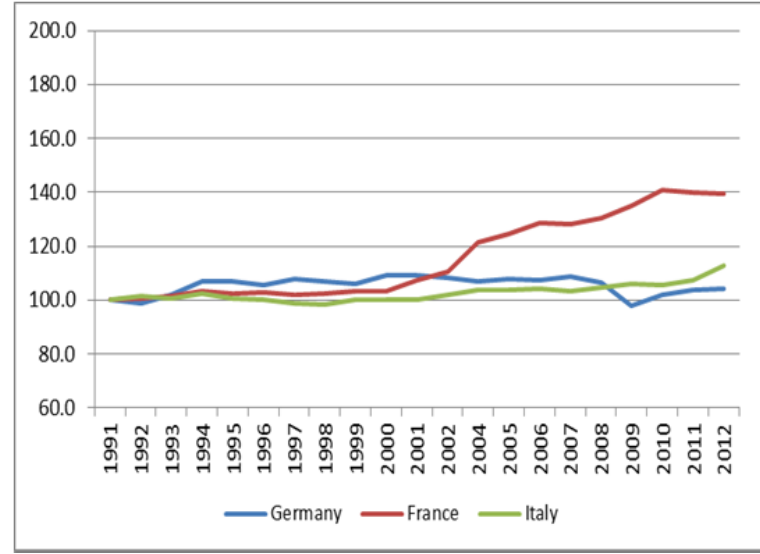

Financial and insurance activities

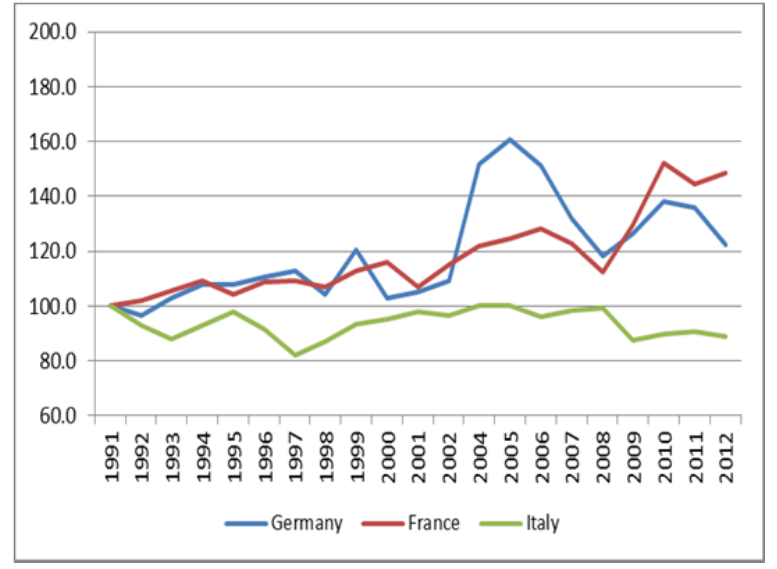

Professional, admin. and support activities

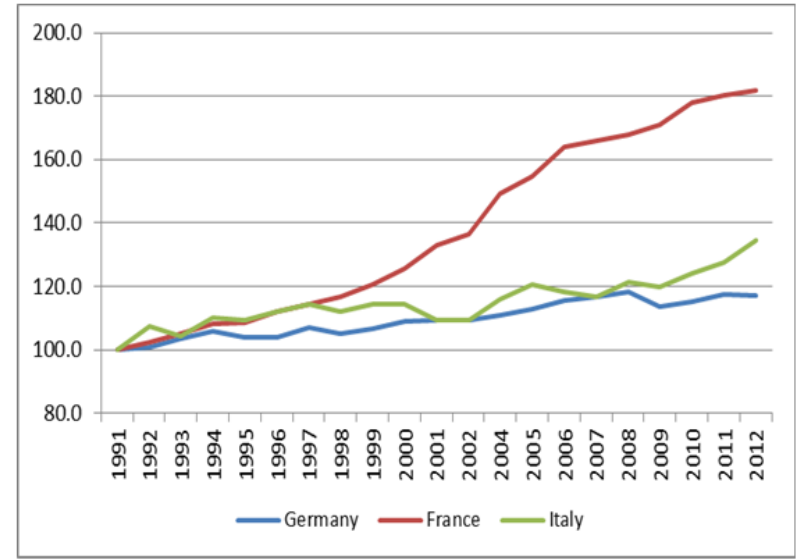

Real estate activities

- Germany —France - Italy

Source: Eurostat.
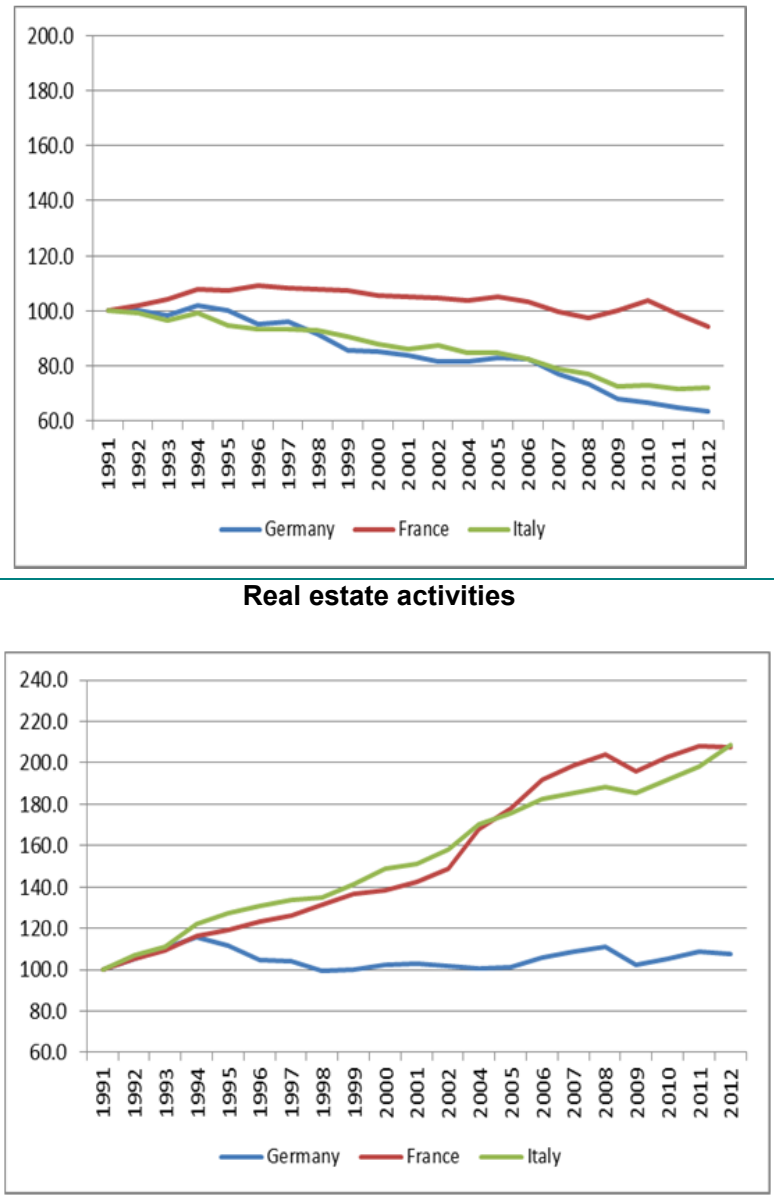

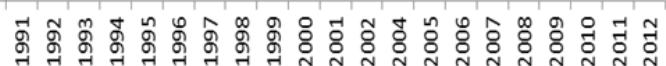


Figure A3

Market services by sub-sector: Ratio between the deflator for household final consumption and for total gross output. 1995-2009

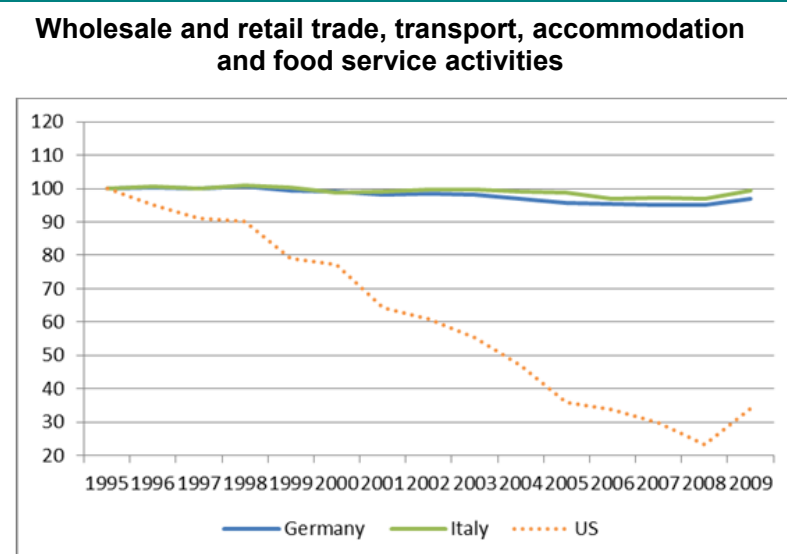

Information and communication
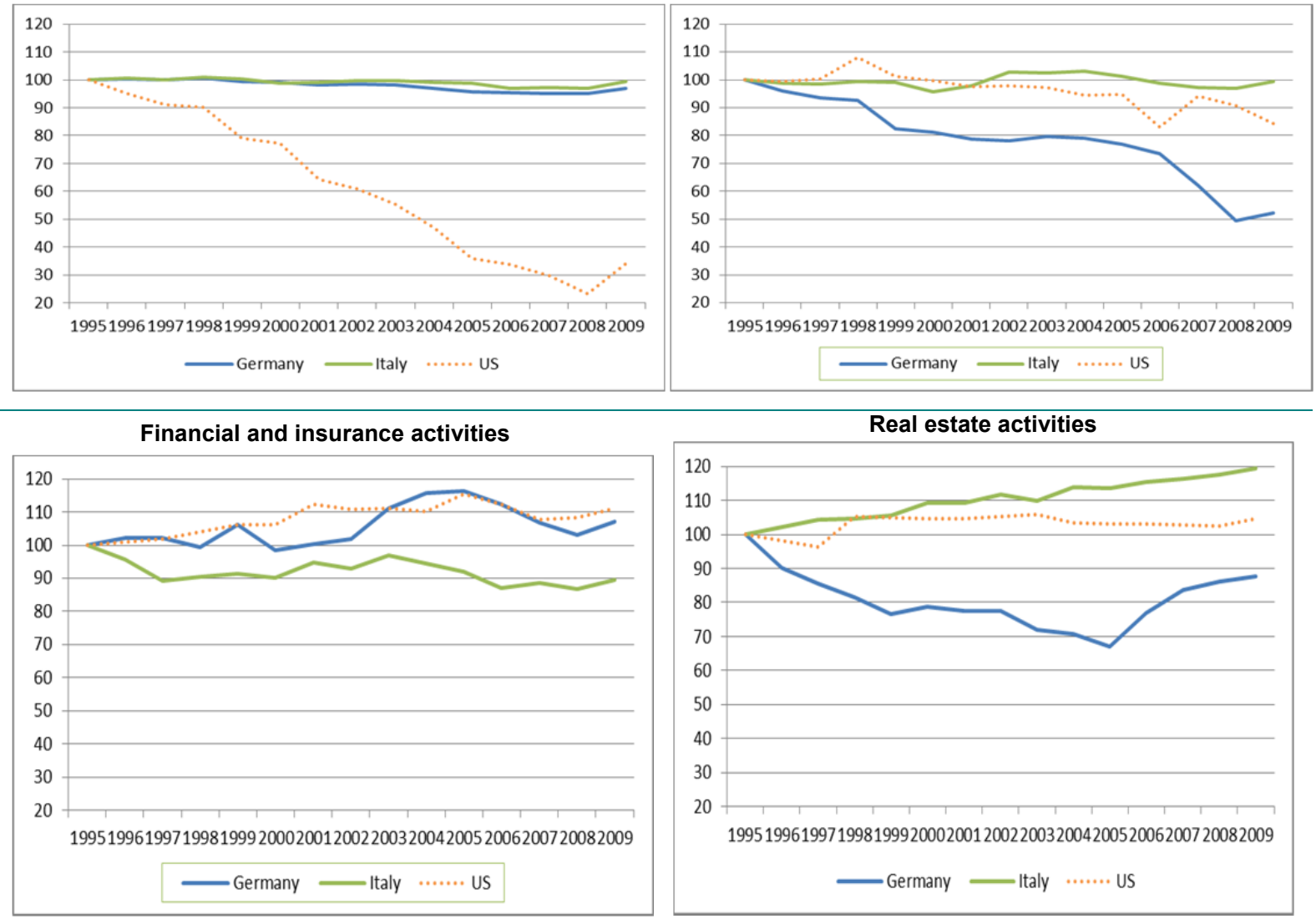

Professional, admin. and support activities

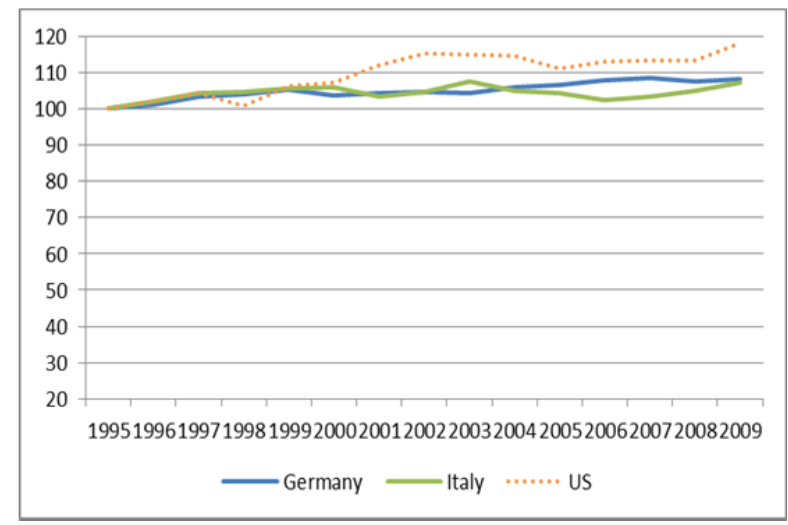

Source: WIOD. 
Figure A4

Share of market services consumed by government in total market services output. Current prices.

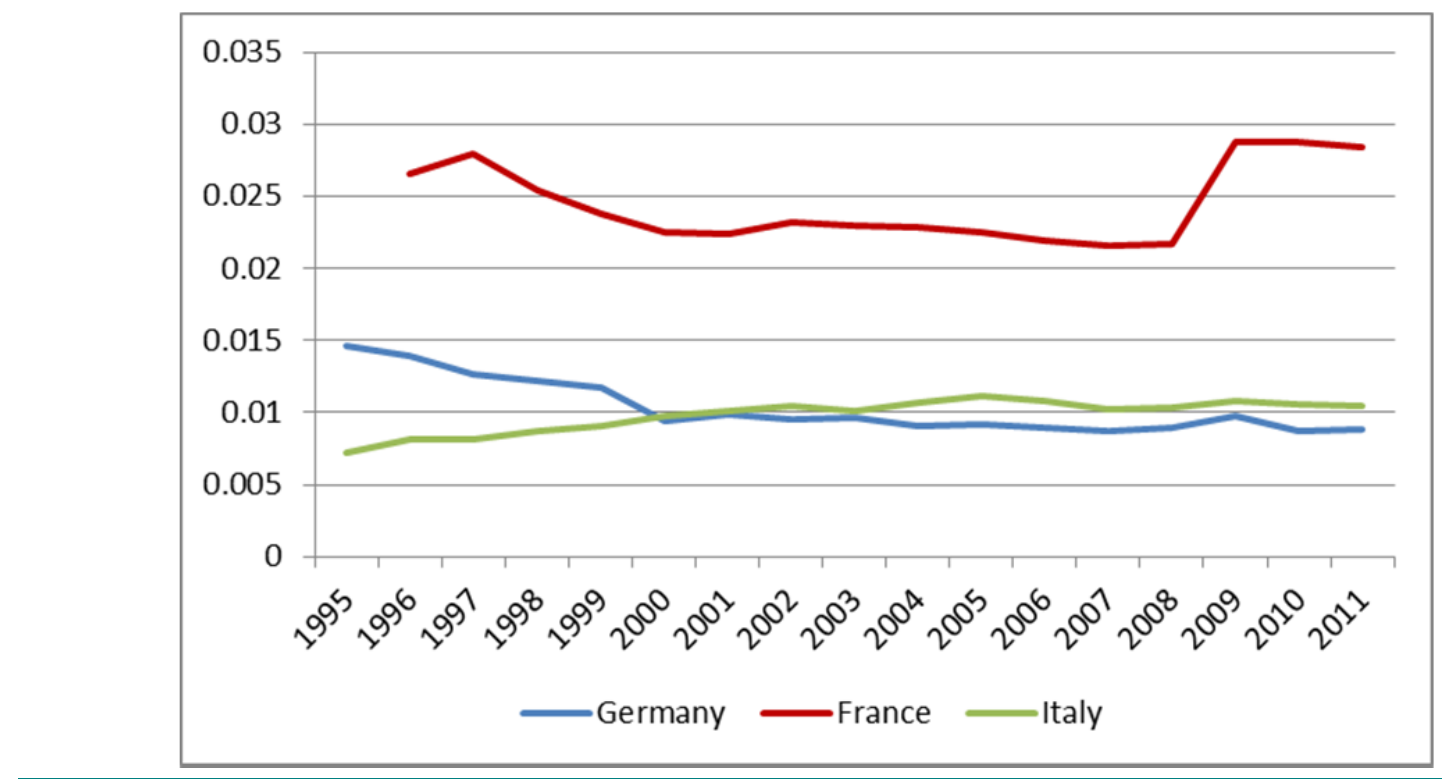

Figure A5

Backward indexes. Effect of an increase of final demand for manufacturing on market services. Input-output matrices provided by Istat, by branches. Current prices. Years 1995, 2000 and 2005.

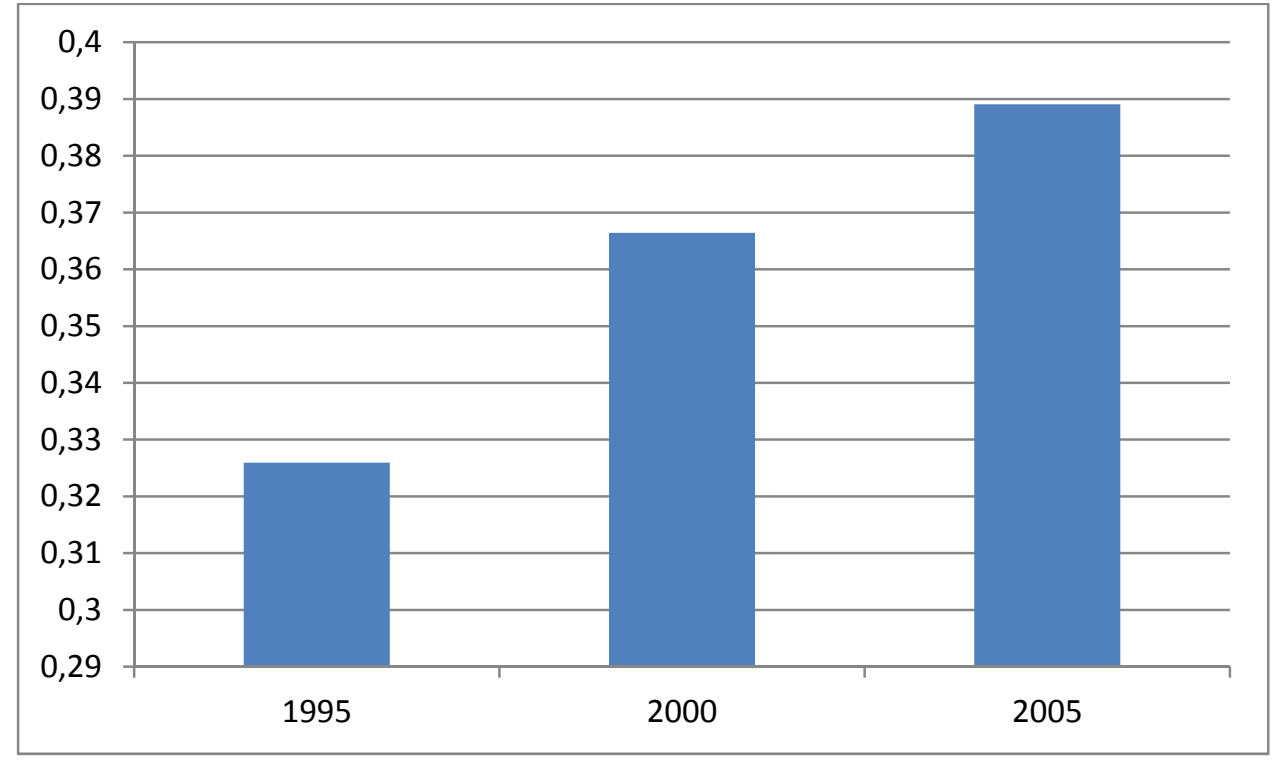


Figure A6

Backward indexes. Effect of an increase of final demand for manufacturing products on manufacturing (panel a) and effect of an increase of final demand for market services on manufacturing (panel b)

(a)

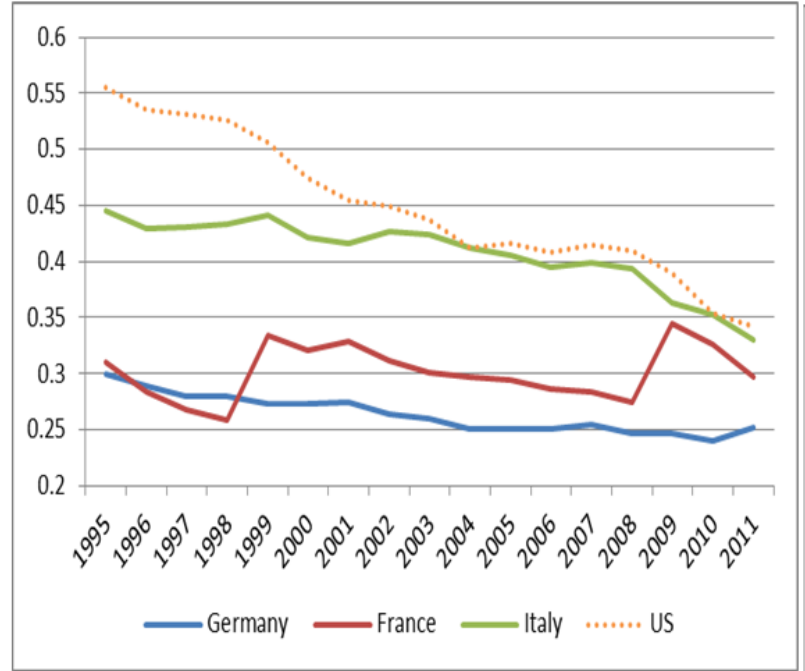

(b)

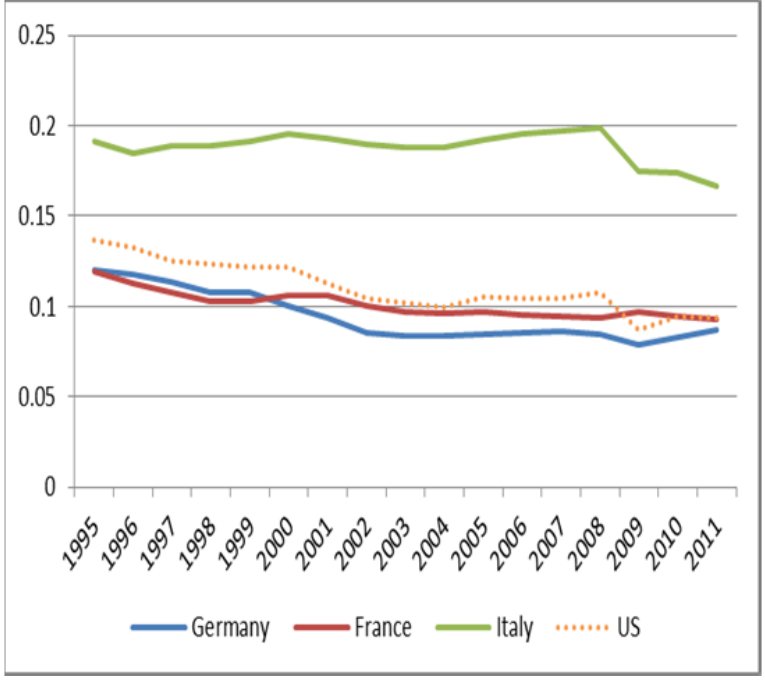

Source: elaboration on WIOD input output data. Current prices. 